Original Research Paper

\title{
Length at first maturity, spawning time, and reproductive output in the females of Hamilton's anchovy (Thryssa hamiltonii Gray, 1835)
}

\author{
Mohammad Mukhlis Kamal ${ }^{1 *}$, Yunizar Ernawati ${ }^{2}$, Nina Nurmalia Dewi ${ }^{3}$ \\ ${ }^{1,2}$ Department of Aquatic Resources Management, Faculty of Fisheries and Marine Science, IPB University, Bogor, \\ Indonesia \\ ${ }^{3}$ Department of Aquaculture, Faculty of Fisheries and Marine Science, University of Airlangga, Surabaya, Indonesia
}

\author{
Article History \\ Received : January $10^{\text {th }}, 2020$ \\ Revised : January $20^{\text {th }}, 2020$ \\ Accepted : January $21^{\text {th }}, 2020$ \\ Published : January $28^{\text {th }}, 2020$ \\ *Corresponding Author: \\ Mohammad Mukhlis \\ Kamal, \\ Department of Aquatic \\ Resource Management, \\ Faculty of Fisheries and \\ Marine Science, IPB \\ University, Bogor, Indonesia; \\ Email: \\ mohammadmukhliskamal@g \\ mail.com
}

\begin{abstract}
The Hamilton's anchovy (Thryssa hamiltonii Gray, 1835) is one of main target species in Indonesian small pelagic fishery. This engraulids member is characterized by short lifespan and fast reproductive cycle. The research aims were to explore the reproduction aspects of the females Hamilton's anchovy in terms of changes in length at first maturity, spawning seasons, and fecundity as well as egg diameter as reproductive output. Fish was collected weekly during 2009 at fish landing site at Gebang Mekar, Cirebon. The fish was length measured, after which ovaries staged for gonadal maturity stage (GMS), fecundity, and eggs diameter. Length frequency data was all linked to this reproductive aspects. The results showed that $\mathrm{L}_{\mathrm{m}}$ was $171.5 \pm 1.62 \mathrm{~mm}$, comparable to annual calculation of $171.05 \pm 0.01 \mathrm{~mm}, \mathrm{~L}_{\mathrm{c}}$ largely tend to smaller than $\mathrm{L}_{\mathrm{m}}$ which indicated to unsustainable fishing. Fish spawns monthly with fecundity range between $3,456-15,843(8,261 \pm 2,776$ eggs), it might be categorized as high fecundity fish relative to its body size. The distribution of eggs diameter showed 2-3 modus, i.e. they are partial spawner fish. The discrepancies in reproductive ouput is suggested to be influenced by seasons which characterized by different environmental conditions.
\end{abstract}

Keywords: Hamilton's anchovy, females, length, spawning, reproductive output

\section{Introduction}

Hamilton's anchovy (Thryssa hamiltonii) is the largest member of genus Thryssa belongs to family Engraulidae. They are widely distributed in all South-east Asia regions except in the Eastern Queensland, North Indian Ocean, and West Pacific (Kuronuma and Abe, 1972; Allen et al., 1999; Froese \& Pauly, 2019). This small pelagic fish inhabits estuaries and mudflats (Allen et al., 1999), and make up an important capture fishery in Indonesia.

Reproduction in fish is the fundamental process by which new offsprings are produced. Early ecological theory recognized the central role that female fecundity plays in the dynamics of populations (reviewed in Caswell, 1989). Understanding the ways in which females parcel out reproductive effort over their lifetime is crucial of both populations and individuals (Maxwell \& Hanlon, 2000), e.g. in term of reproductive capacity and adult size composition in response to fishing activity (Poisson \& Fauvel, 2009), and assessing variability in reproductive timing both among and within populations (LowerreBarbieri et al., 2011).
This study was aimed to explore the changes in length at first maturity, spawning season, and reproductive output of the female Hamilton's anchovy. Female fishes has been more appreciated compared to males, as reproductive investment in females are relatively easier to be estimated compared to males (Trippel, 2003), in part because offspring production is limited to greater degree of eggs than sperm production (Murua \& Saborida-Rey, 2003), and in which the quantity of spawned eggs has been positively correlated with maternal length, age and nutritional conditions (Kjesbu et al., 1991; 1996). In other words, the reproductive output is more visible in females compared to males; the oocytes are apparently straightforward in expressing the reproductive output as counting and measuring eggs could be conducted macroscopically.

\section{Materials and methods}

Sampling site and handling

Fishes were collected at fish landing site in Gebang Mekar Village, the District of Cirebon (Figure 1). Fishes 
were randomly selected and preserved with $8 \%$ of formaldehyde, then transported to Biomakro Laboratory, IPB University. Sampling campaign was conducted throughout year 2009 with weekly intervals.

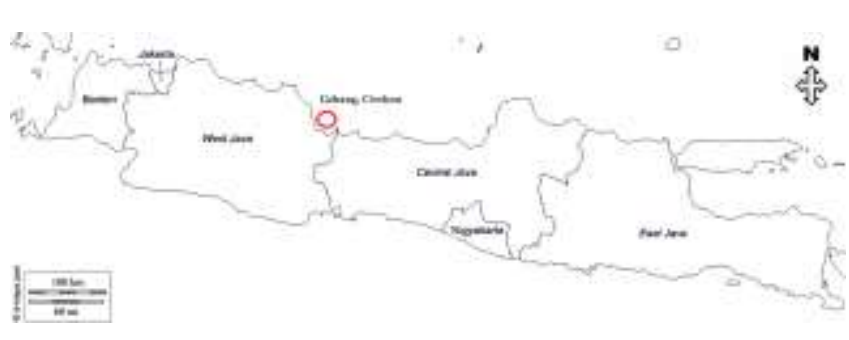

Figure 1. Fish landing site and study area of Hamiltoni's Thryssa (Thryssa hamiltonii) collection (shown by red circle) at Gebang, Cirebon.

\section{Laboratory Protocol}

In laboratory, each fish was total length measured and weighted to the nearest $0.1 \mathrm{~mm}$ and $0.01 \mathrm{~g}$, respectively, then dissected for morphological examination of the ovaries. It was staged into immature, develoving, maturing, spawning, and spent categories (Effendie, 1979). The maturing ovaries were weighted to the nearest $0.001 \mathrm{~g}$, and fixed into Bouin's solution for fecundity and eggs examination. Fecundity was defined as total amount of eggs which sub-sampled by $30 \%$, which each egg was taken from anterior, middle, and posterior parts of the ovary (Effendie, 1979). Eggs diameter was measured under binocular microscope equipped with one $\mathrm{mm}$ scaled object glass, from 120 maturing females to account 30,000 eggs in total. Its measurement was performed.

\section{Data Analysis}

Length at first maturity $\left(\mathrm{L}_{50}\right)$ is determined by fitting the logistic equation (Prager et al., 1994):

$$
p=\left[1+e^{-r(x-x} 50^{)}\right]^{-1}
$$

where $\mathrm{p}$ is the estimated proportion in size class, $\mathrm{r}$ is a fitted parameter, $\mathrm{x}$ is the total length, $\mathrm{x}_{50}$ is the length at which $50 \%$ of marure females of each size class. The result of monthly $\mathrm{L}_{50}$ was averaged and compared to combined one year data using Spearman-Karber formula (Udupa, 1986). In estimating spawning strategy, eggs diameter data is treated as length data for further analysis using length frequency distribution (FISAT II) (Gayanilo et al., 2005). All data obtained were proceeded for normality test prior to mean (parametric) or median (nonparametric) comparison (Fowler \& Cohen, 1997).

\section{Results and discussions}

\section{Results}

Length at First Maturity $\left(L_{m}\right)$

Total amount of fish collected in one year was 1,289 females Hamilton's anchovy of which 583 individuals were maturing females, i.e. fishes with the $4^{\text {th }}$ gonadal maturity. A monthly changes in $\mathrm{L}_{50}$ of the Hamilton's anchovy is presented in Figure 2. The results showed that first length maturity size varied between 169 - $175 \mathrm{~mm}$ (171.5 $\pm 1.62 \mathrm{~mm})$ (T-Test, P>0.05), with coefficient variation less than $1 \%$. This results indicated no significant changes in $\mathrm{L}_{\mathrm{m}}$ among and between months. If those maturing females are grouped as one year, according to Spearman-Karber formula, $\mathrm{L}_{\mathrm{m}}$ value was $171.05 \pm 0.01 \mathrm{~mm}$. By comparing $\mathrm{L}_{\mathrm{m}}$ with length at captured $\left(\mathrm{L}_{\mathrm{c}}\right)$, there was a tendency that females were capture at smaller size, but February 2009 (Figure 3.), though $\mathrm{L}_{m}$ and $\mathrm{L}_{c}$ was indifferent ( $\left.\mathrm{p}>0.05\right)$.

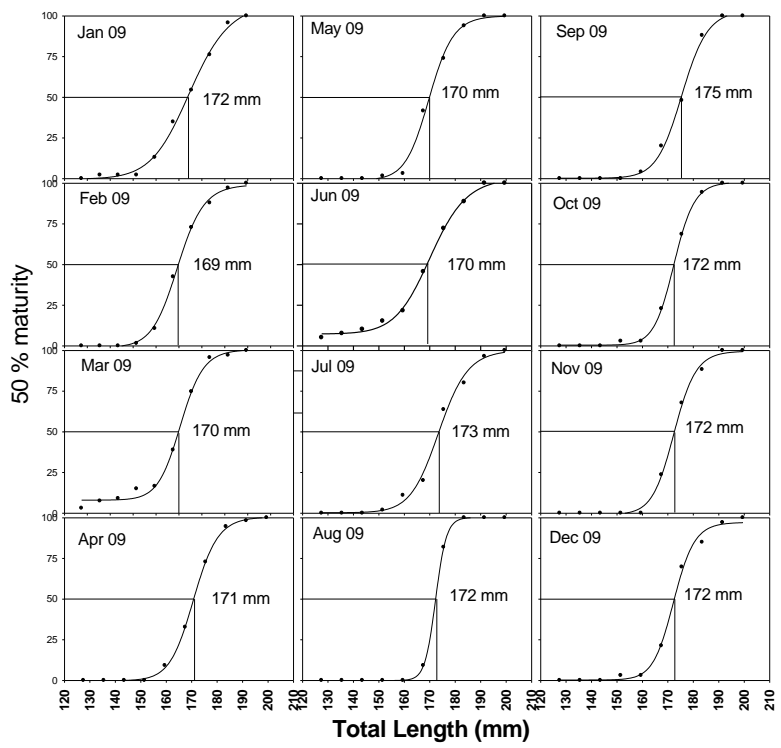

Figure 2. Size at which $50 \%$ of maturing females $\left(\mathrm{L}_{\mathrm{m}}\right)$ in the Hamilton's anchovy (T. hamiltonii) by monthly basis.

\section{Gonad Maturity Stage}

Morphological examination on 1,294 ovaries of Hamilton's anchovy showed that the proportion of maturing females ranged between $32-58 \%$, indicating a continuing spawning season throughout the year of this 
species. Number of observed females fluctuated from 20 in August to 154 females in May (Figure 4.). Months with higher proportion of maturing females occurred in February, June, and August. However, this might unsafe to conclude the peak spawning seasons occurred in these months as the proportion was indifferent to the others ( $\mathrm{p}$ $>0.05)$.

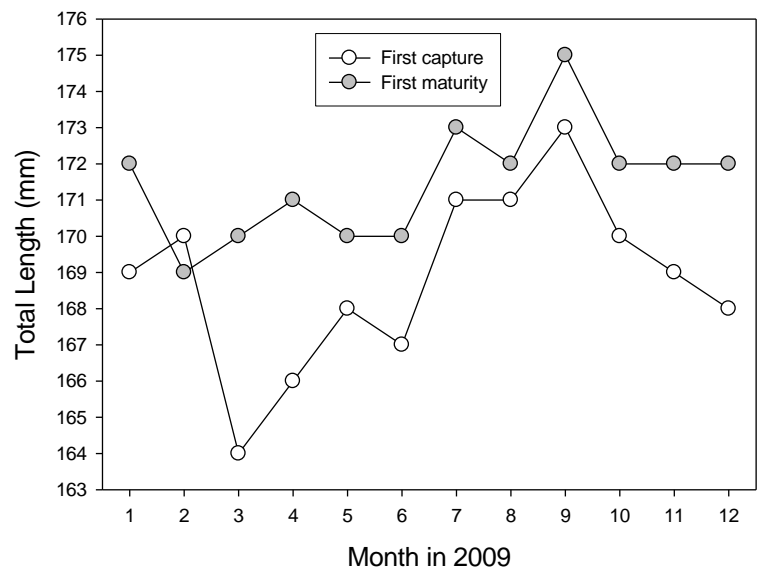

Figure 3. Comparison between length at first maturity $\left(\mathrm{L}_{\mathrm{m}}\right)$ to length at captured $\left(\mathrm{L}_{\mathrm{c}}\right)$ in females of the Hamilton's anchovy (Thryssa hamiltonii).

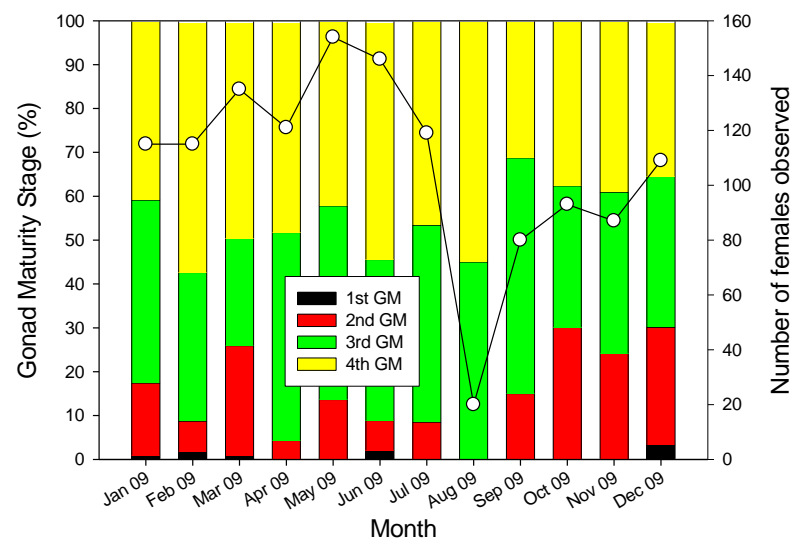

Figure 4. Proportion of each gonad maturity (GM) stages comparing between months in the female Hamilton's anchovy (T. hamiltonii).

Fecundity

Monthly examination on 8-14 females made to a total of 121 ovaries observed for one year, total fecundity of the Hamilton's anchovy varied between 3,456 - 15,843 eggs $(8,261 \pm 2,776$ eggs $)$. The results indicated for high fecundity of relatively small mature females with 120-195 $\mathrm{mm}$ in length (Figure 5). The fecundity increased steadily from January to April and decreased sharply in May preceding another increased until June, then tend to decrease again in the end period of the year.

Eggs Diameter

Having observed on approximately 30,000 eggs represented by 10 maturing females each month, eggs diameter ranged between $225-700 \mu \mathrm{m}$ and distributed into 15 size classes (Figure 6). The results confirm that $T$. hamiltonii is partial spawner fish which characterized by 2-3 eggs size groups.

Based on the size distribution, the average eggs diameter varied between 256.5 - $704.5 \mu \mathrm{m}$ during which during December - June showed a slightly larger size compared to July - November, i.e. $544.5 \mu \mathrm{m}$ compared to $480.5 \mu \mathrm{m}$.

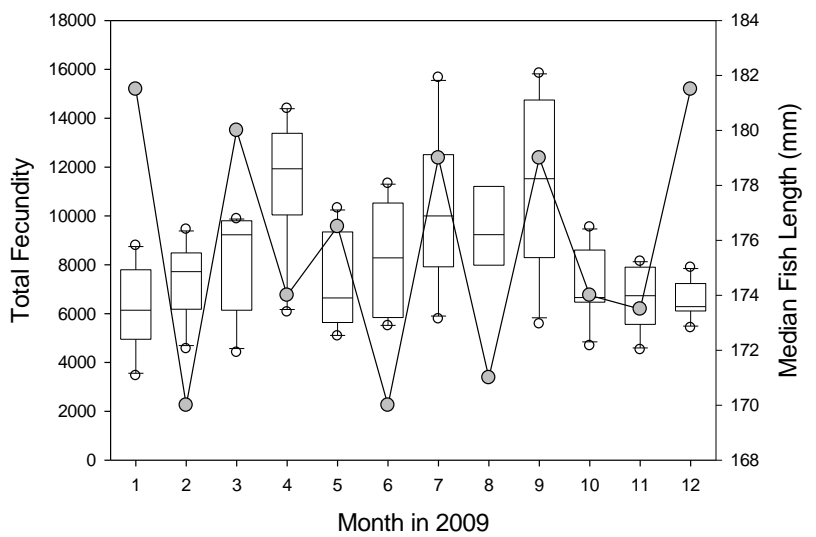

Figure 5. Monthly variation in fecundity (box plots) at body length (black circles) in the Hamilton's anchovy (T. hamiltonii)

\section{Discussions}

The results showed a tendency of $\mathrm{L}_{\mathrm{c}}$ was mostly smaller than that $\mathrm{L}_{\mathrm{m}}$ in $T$. hamiltonii. This might be an indication that the fishery has been unsustainably managed (Dickert, 2012). Fontoura et al., (2009) stated that an appropriate estimation on $\mathrm{L}_{\mathrm{m}}$ is important for fish stock management, therefore the dominating catch of smaller individuals in the study area is a clear sign of high exploitation rate at which population is largely composed by younger and smaller individuals. This implies to allowable size at capture, gears regulation, accessible fishing ground and season. In long term fishery, such condition will cause to growth overfishing (King, 1997). 


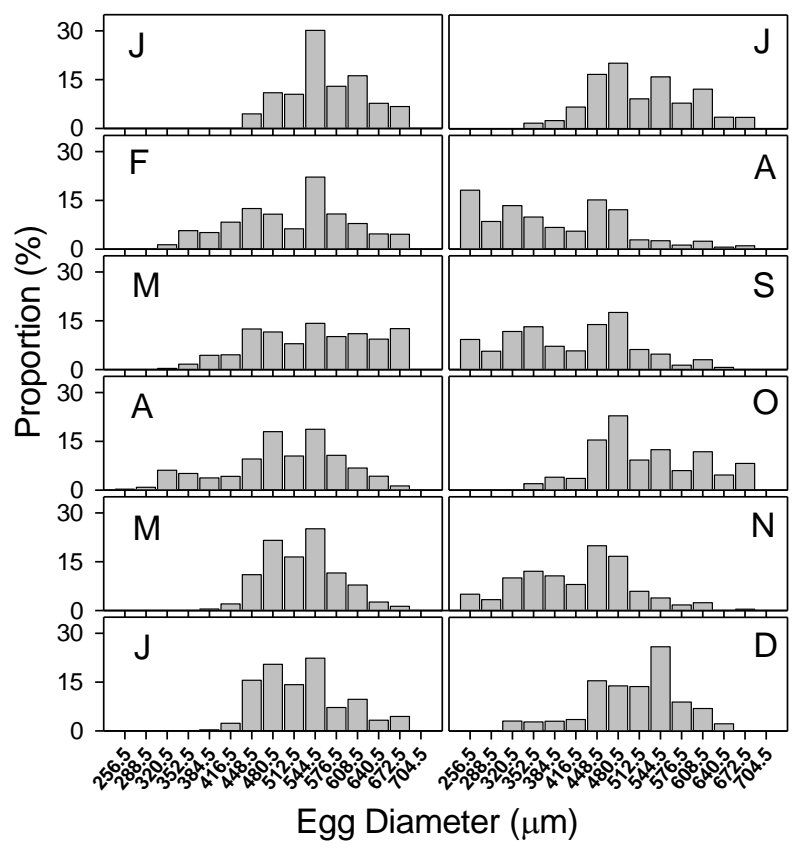

Figure 6. Monthly variation of egg diameter $(\mu \mathrm{m})$ in the Hamilton's anchovy (Thryssa hamiltonii).

An extended spawning season in the anchovy (Family Engraulidae) has long been known. As cited from Hunter and Leong (1981) in Motos (1996), that the development of oocytes in the Californian anchovy (Engraulis mordax) during the reproductive season is a continuous process with presence of all the oocyte stages and with a new group of oocytes maturing and being released every other week or 10 days in the period of peak spawning. In other engraulids, Lisovenko \& Adrianov (1996) reported that Encrasiolus ponticus spawns from May to August in the year under the influence of higher temperature during summer. In the similar genus of Thryssa, Qureshi (1983) noticed from Pakistan's waters that T. mystax has two spawning season from September - March and June - August. Moreover, with special notes on tropical region of Indonesia, Andamari \& Milton (1998) found that Encrachicolina heterolobus and E. devisi reached sexual maturity within three months and spawns continuously thereafter. With special notes on $T$. hamiltonii of different latitude in the Arabian Gulf, Hussein \& Ali (1985) found a single and prolonged spawning period extending from December to April. Based on these facts, it is suggested that a protracted and continuing spawning activity in $T$. hamiltonii in the northern Java Sea is maintained depending on environmental factors such as temperature and food availability. As temperature in the tropics are relatively stable, food availability would be a plausible explanation.
As reported by Supriadi \& Kamal (2009, unpublished), the incoming rivers ended at Cirebon coastal waters bring about organic materials enriching the primary production in this area.

High number of fecundity in small pelagic fish is thought to be common phenomenon. Of five species of anchovies, Andamari et al. (2002) concluded that high fecundity in tropical anchovies is an expression of reproductive strategy that is adapted to high natural mortality. This is in agreement with other engraulids found in temperate (Lisovenko \& Andrianov, 1996; Basilone et al., 2003), sub-tropic (Arockiamary et al., 2011), and tropical regions (Maack \& George, 1999; Andamari et al., 2002). Such phenomenon is commonly found in marine fish species (Murua \& Saborido-Rey, 2003). As small pelagic fishes, Family Engraulidae are said to be r-strategy adapted fish that inhabiting instable environments, characterized by shorter life span, high growth, and high fecundity.

In comparison with other engraulids, Arockiamary et al. (2011) found that eggs diameter was $920-990 \mu \mathrm{m}$ (T. dussumieri); $980-1003 \mu \mathrm{m}$ (T. mystax), and for similar species in Bima Bay, West Nusa Tenggara, was $1,200 \mu \mathrm{m}$. The discrepancies in engraulids egg size have been found to vary among engraulids species (LlianosRivera and Castro, 2004). In general, Wootton (1990) has pointed out that variations in size of the spawning females and shifts in energy allocation from reproduction to growth as the spawning season progresses may influence the egg volume. Alternatively, Bagenal (1971) has concluded that environmental factors link to seasonal variations in photoperiod, seawater temperature, and food supply during the spawning season may affect the reproductive output.

\section{Conclusions}

Length at first maturity $\left(\mathrm{L}_{\mathrm{m}}\right)$ in $T$. hamiltonii was relatively constant for the whole year period and mostly larger than length at first catch $\left(\mathrm{L}_{\mathrm{c}}\right)$, indicating of unsustainable fishing which highly leads to overfishing for long term period. They spwan througout the year as partial spawners, and by characterized high number of eggs relative to body size. Reproductive output is likely to be influenced by environmental factors adapted by small and short lifespan of pelagic fishes.

\section{Acknowledgement}

The authors would like to thank to Subandi for samples collection. Pandu Mahendratama and Ilmi Ading Puteri Sheima are grateful for partly laboratory works. Authors also appreciate the effort of unanimous reviewers for input and comments to improve the quality of this paper. 


\section{References}

Allen, G., Swainston, R. \& Ruse, J. 1999. Marine Fishes of South-east Asia: A Field Guide For Anglers and Divers. Periplus Edition Ltd. Singapore. 292p. https://www.amazon.com/Marine-Fishes-SouthEast-Asia-Anglers/dp/9625932674

Andamari, R., Milton, D. \& Zubaidi, T. 2002. Reproductive biology of five species of anchovies (Engraulidae) from Bima Bay, Sumbawa, Nusa Tenggara. Indonesian J. of Agricultural Science, 32(2):37-42.

https://media.neliti.com/media/publications/6335 3-none-6a396d09.pdf

Araújo, F.G., Silva, M.A., Santos, J.N.S. \& Vasconcellos, S.M. 2008. Habitat selection by anchovies (Clupeiformes: Engraulidae) in a tropical bay at Southeastern Brazil. Neotropical Ichthyology, 6(4): 583-590.

http://dx.doi.org/10.1590/S1679$\underline{62252008000400006}$

Arockiamary, A., Vijayalakshmi, S. \& Balasubramanian, T. 2011. Engraulidae eggs from Parangipettai waters. European J. of Experimental Biology, 1(2):125-131.

www.pelagiaresearchlibrary.com

Bagenal, T.B. 1971. The interrelation of the size of fish eggs, the date of spawning and the production cycle. Journal of Fish Biology, 3: 207-219. https://onlinelibrary.wiley.com/doi/abs/10.1111/j. 1095-8649.1971.tb03665.x

Basilone, G., Patti, B., Bonanno, A., Cuttitta, A., Vergara, A.R., Garcia, A., Mazzola, S. \& Buscaino, G. 2003. Reproductive aspects of the European anchovy (Engraulis encrasicolus): six years of observation in the Strait of Sicily. MedSudMed Technical Documents, (5):67-78.

http://www.faomedsudmed.org/pdf/publications/t d5/td5-basilone 1.pdf

Caswell, H. 1989. Matrix population models. Sinauer, Sunderland. 710p.

https://www.sinauer.com/media/wysiwyg/tocs/M atrixPopulationModels2.pdf

Dickert, E.K. 2012. Growth overfishing: the race to fish extends to the dimesion of size. Environmental Resource Economy. DOI 10.1007/s10640-012-9542-x
Effendie, M.I. 1979. Metode biologi perikanan. Yayasan Dewi Sri. Bogor. $111 \mathrm{hlm}$.

Fontoura, N.F., Braun, A.S. \& Milani, P.C.C. 2009. Estimating size at first maturity $\left(\mathrm{L}_{50}\right)$ from Gonadosomatic Index (GSI) data. Neotropical Ichthyology, 7(2): 217-222. http://dx.doi.org/10.1590/S1679$\underline{62252009000200013 .}$

Fowler, J. \& Cohen, L. 1997. Practical statistics for field biology. John Wiley \& Sons. Chichester, New York, Brisbane, Toronto, Singapore. 259p.

https://www.wiley.com/enus/Practical+Statistics+for+Field+Biology $\% 2 \mathrm{C}+2$ nd+Edition-p-9780471982968

Froese, R., Pauly, D. Thryssa hamiltonii 2019. http://www.fishbase.org. [Retrieved on Desember 2019].

Gayanilo F.C.Jr., Sparre, P. \& Pauly D. 2005. FAO ICLARM Stock Assessment Tools (FiSAT). User's guide. FAO Computerised Information Series (Fisheries) No. 8 FAO. Rome. 126p. http://www.fao.org/3/y5997e/y5997e00.htm

Hussein, N.A. \& Ali, T.S. 1985. Some biological aspects of Thryssa mystax and Thryssa hamiltonii in KhorAl-Zubair, Northwest Arabian Gulf. Marine Science, 2:151-162.

https://www.academia.edu/8684195/

Kamal, M.M. \& Supriyadi. 2009. The anchovies (famili: Engraulidae) in Cirebon waters (unpublished). $61 \mathrm{p}$.

King, M. 1997. Fisheries biology, assessment and management. Fishing News Book. Blackwell Science Pty Ltd. Malden, Australia. 400p. https://www.wiley.com/enus/Fisheries+Biology\%2C+Assessment+and+Ma nagement $\% 2 \mathrm{C}+2 \mathrm{nd}+$ Edition-p-9781405158312

Kjesbu, O.S., Klungsøyr, J., Kryvi, H., Witthames, P.R. \& Greer Walker, M. 1991. Fecundity, atresia, and egg size of captive Atlantic cod (Gadus morhua) in relation to proximate body composition. Canadian Journal of Fisheries and Aquatic Sciences, 48: 2333-43. https://doi.org/10.1139/f91-274

Kjesbu, O.S., Kryvi, H. \& Norberg, B. 1996. Oocyte size and structure in relation to blood plasma steroid hormones in individually monitored, spawning 
Atlantic cod. Journal of Fish Biology, 39: 1197215.

https://doi.org/10.1111/j.10958649.1996.tb01789.x

Kuronuma, K. \& Abe, Y. 1972. The fishes of Kuwait. KISR. 173p.

https://www.google.com/search?q=Kuronuma, $+\mathrm{K}$ $.+\% 26+$ Abe,+ Y.++1972.++The+fishes+of+Kuwa it. + KISR. $+173 p$

Lisovenko, L.A. \& Andrianov, D.P. 1996. Reproductive biology of anchovy (Engraulis encrasicolus ponticus Alexandrov 1927) in the Black Sea. Scientia Marina: 60 (Supl. 2): 209-218. http://scimar.icm.csic.es/scimar/pdf/60/sm60s220 9.pdf

Llianos-Rivera, A. \& Castro, L.R. 2003. Latitudinal and seasonal egg-size variation of the anchoveta (Engraulis ringens) off the Chilean coast. Fishery Bulletin, 102(1):207-212.

https://www.researchgate.net/publication/237242 $\underline{526}$

Lowerre-Barbieri, S.K., Ganias, K., Saborido-Rey, F., Murua, H. \& Hunter, J.R. 2011. Reproductive timing in marine fishes: variability, temporal scales, and methods. Marine and Coastal Fisherie: Dynamics, Management, and Ecosystem Science, 3:71-91.

http://www.bioone.org/doi/full/10.1080/1942512 $\underline{0.2011 .556932}$

Maack, G. \& George, M.R. 1999. Contribution to the reproductive biology of Encrasicholina punctifer Fowler, 1938 (Engraulidae) from West Sumatera, Indonesia. Fisheries Research, 44(2):113-120. http://citeseerx.ist.psu.edu/viewdoc/download?doi $=10.1 .1 .555 .8728 \& \mathrm{rep}=\mathrm{rep} 1 \&$ type $=$ pdf

Mahendra, P. 2011. Laju eksploitasi dan variasi temporal keragaan reproduksi ikan banban Engraulis grayi (bleeker, 1851) betina di Pantai Utara Jawa (Oktober-Maret). Undergraduate Thesis. Faculty of Fisheries and marine Science. Bogor Agricultural University. 61p.

Maxwell, M.R. \& Hanlon, R.T. 2000. Female reproductive output in the squid Loligo pealeii: multiple egg clutches and implications for a spawning strategy. Marine Ecology Progress Series, 199:159-170.

https://www.jstor.org/stable/24855937
Motos, L. 1996. Reproductive biology and fecundity of the Bay of Biscay anchovy population (Engraulis mordax L.). Scientia Marina, 60 (Supl. 2):195207.

https://pdfs.semanticscholar.org/9ad1/db31bc06b 0b2153964e2879b9226b8c13958.pdf

Murua, H. \& Saborido-Rey, F. 2003. Female reproductive strategy of marine fish species of the North Atlantic. J. of Northwestern Atlantic Fishery Science, 33:23-31. https://digital.csic.es/bitstream/10261/26868/1/mu rua.pdf

Poisson, F. \& Fauvel, C. 2009. Reproductive dynamics of swordfish (Xiphias gladius) in the southwestern Indian Ocean (Reunion Island). Part 2: fecundity and spawning pattern. Aquatic Living Resources, 22:59-68.

https://www.researchgate.net/publication/29494737

Prager, M.H., Saila, S.B. \& Recksiek, C.W. 1994. FISHPARM: A microcomputer program for parameter estimation of nonlinear models in fishery science. Old Dominion University Research Foundation. USA. 36p.

Qureshi, S. 1983. Growth rate and spawning season of three marine fishes of Pakistan. Pakistani J. Research of Agriculture, 4(4):263-274.

Sheima, I.A.P. 2011. Laju eksploitasi dan variasi temporal keragaan reproduksi ikan banban (Engraulis grayi) betina di Pantai Utara Jawa pada Bulan April - September. Undergraduate Thesis. Faculty of Fisheries and marine Science. Bogor Agricultural University. 72p.

Trippel, E.A. 2003. Estimation of male reproductive success of marine fishes. Journal of Northwest Atlantic Fisheries Science, 33: 81-111. https://journal.nafo.int/Volumes/Articles/ID/565/

Udupa, K.S. 1986. Statistical method of estimating the size at first maturity in fishes. Fishbyte, 4(2): 8-10. http://agris.fao.org/agrissearch/search.do?recordID=QW2012000961

Wootton, R. 1990. Ecology of teleost fishes. Chapman \& HaHall. London. 404p. https://trove.nla.gov.au/work/16614123?selectedv ersion=NBD6476848 